\title{
EFFECT OF PREHEATED JATROPHA OIL AND JATROPHA OIL METHYL ESTER WITH PRODUCER GAS ON DIESEL ENGINE PERFORMANCE
}

\author{
C. Nayak ${ }^{1, *}$, B. P. Pattanaik ${ }^{2}$ and S. K. Nayak ${ }^{2}$ \\ ${ }^{1}$ Department of Mechanical Engineering, SOA University \\ Bhubaneswar- 30, Odisha, India \\ *E-mail- Chandra_kec@ rediffmail.com \\ Phone- +91-9861938217 \\ ${ }^{2}$ School of Mechanical Engineering, KIIT University \\ Bhubaneswar-751024, Odisha, India
}

\begin{abstract}
The present experimental study demonstrates the performance and emission characteristics of a single cylinder dual fuel diesel engine with producer gas as the primary fuel and diesel, preheated Jatropha oil and Jatropha oil methyl ester as injected fuels. In order to reduce the viscosity of Jatropha oil, a shell and tube type heat exchanger was designed and fabricated for preheating Jatropha oil using engine exhaust gas. The performance parameters, such as brake specific fuel consumption, brake thermal efficiency and exhaust gas temperature, have shown improved results with baseline diesel and producer gas, whereas the above parameters are very close to other test fuels under different loading conditions. All the emission parameters are found to be on the higher side for preheated oil- compared to diesel-producer gas dual fuel operation at all load conditions. With Jatropha oil methyl ester-producer gas dual fuel operation, however, emission parameters such as $\mathrm{CO}_{2}$, smoke and $\mathrm{NOx}$ are higher compared to diesel-producer gas operation. The smoke emission for preheated Jatropha oil-producer gas dual fuel operation is approximately $60 \%$ higher than that of diesel-producer gas operation at full load. From the present experimental investigation it may be concluded that alternative fuel combinations such as preheated Jatropha oil-producer gas and Jatropha oil methyl ester-producer gas can successfully replace diesel as the major fuel in diesel engines with little modification. The present paper also recommends further investigation to improve fuel properties and in-cylinder combustion phenomena of preheated Jatropha oil and its methyl ester before use in a diesel engine.
\end{abstract}

Keywords: Dual fuel, diesel engine, producer gas, performance, emission.

\section{INTRODUCTION}

Due to the high brake thermal efficiency of diesel engines compared to gasoline engines they have become more popular in the transportation and agriculture sector. As a result of the rapid depletion, rising price, uncertainties over the supply of petroleum fuels and the need to clean up the environment, an intensive research for alternative fuels has been triggered (Azad, Ameer Uddin, \& Alam, 2012; Edwin, Nagarajan, \& Nagalingam, 2008; Ghobadian, Najafi, \& Nayebi, 2013; Mat Yasin, Mamat, Sharma, \& Yusop, 2012; Rahim, Mamat, Taib, \& Abdullah, 2012; Senthil Kumar, Ramesh, \& Nagalingam, 2003a; Soon, Rus, Anika, \& Hasan, 2013). A lot of research is conducted into renewable fuels which are clean burning, and are being investigated as alternative 
fuels (Aziz Hairuddin, Wandel, \& Yusaf, 2013; Sundar Raj \& Sendilvelan, 2010; Yusaf, Hamawand, Baker, \& Najafi, 2013). Alcohols, vegetable oil and its derivatives, gaseous fuel such as hydrogen, compressed natural gas (CNG), liquid petroleum gas (LPG) and producer gas are used as good alternative fuels for internal combustion (IC) engines in dual fuel mode (Azad et al., 2012; Lata \& Misra, 2010; Senthil Kumar, Ramesh, \& Nagalingam, 2003b). The physical-chemical properties of vegetable oil are comparable with diesel and can be used to run a diesel engine without any modification (Senthil Kumar et al., 2003a). Due to higher viscosity and lower volatility the nature of vegetable oil causes engine problems such as mixture formation, atomization and spray penetration, resulting in low brake thermal efficiency, increased smoke and gummy deposits on engine components (Kalam \& Masjuki, 2004; Ramadhas, Jayaraj, \& Muraleedharan, 2008). The fuel preheating technique offers the advantage of using heavy fuels in normal diesel engines without any modification. Past investigations have showed that preheated vegetable oils in diesel engines resulted in improved brake thermal efficiency, reduced smoke and particulate emissions (Bari, Lim, \& Yu, 2002). Dual fuel operation in diesel engines over single mode operation results in lower smoke emissions with improved thermal efficiency. A conventional diesel engine can be easily be modified to dual fuel mode. In a dual fuel engine, a gaseous fuel is inducted as the primary fuel and ignited by diesel/neat vegetable oil/bio-diesel as the pilot fuel (Nwafor, 2000). Jatropha curcas is very popular among the rural population of India due to its many uses. This plant can grow in the western part of India and consumes less water. Depending upon its cultivation, seed collection, oil extraction, and bio-diesel production processes, this plant can generate large-scale employment (Pradeep \& Sharma, 2007). Jatropha biodiesel is a sulfur free renewable fuel and still exhibits excellent lubricant properties (Sharma, 2003). It is safer than diesel oil due to its higher flash and fire point. Jatropha biodiesel possesses low calorific value and enhances nitrogen oxide (NOx) emissions due to the presence of oxygen, however, the presence of oxygen results in a lower carbon monoxide $(\mathrm{CO})$ and hydrocarbon $(\mathrm{HC})$ emission as result of the complete combustion of bio diesel. Higher bulk modulus is responsible for the dynamic advance of injection timing in bio diesel fuelled engines (Szybist, 2003). Biodiesels are the mono alkyl esters of long chain fatty acids derived from renewable sources, for use in diesel engines. Bio-diesel from Jatropha oil (JO) is produced through transesterification processes in which straight vegetable oils are mixed with methanol in the presence of catalyst. Catalysts such as sodium or potassium hydroxide are generally used (Murugesan, Umarani, Subramanian, \& Nedunchezhian, 2009). The objective of the transesterification process is to reduce the viscosity and density of neat vegetable oil and bring it closer to that of diesel. The bio-diesel thus obtained is engine friendly and its properties are very close to diesel fuel (Senthil Kumar, Ramesh, \& Nagalingam, 2001; Sharma, 2003). Many researchers have reported that in spite of the many advantages of Jatropha oil bio-diesel (JOBD), it emits higher NOx emissions compared to diesel fuel (Chairman, 2003; Sharma, 2003) which is a serious environmental effect. The presence of oxygen in its structure, and higher bulk modulus and boiling point of JOBD are the factors responsible for aggravating the NOx emission (Sharma, 2003; Szybist, 2003).

Producer gas is a clear burning gas obtained from solid bio fuels by converting them into gaseous fuel inside a gasifier. A gasifier is a simple chemical reactor where both physical and chemical reactions take place. Producer gas can be generated from various sources such as bagasse, coir-pith, ground nut shell, saw dust, straw wood chips etc. From the literature it is revealed that according to direction of flow, gasifiers are of 
three types: up draft, down draft and cross draft (Ramadhas et al., 2008). The composition of producer gas obtained during gasification is measured using gas chromatography as shown in Table 1. Krishna and Ajit Kumar (1994) used coffee husk as a biomass for gasification and analyzed the performance of a diesel engine on dual fuel mode. They found that the maximum percentage diesel replacement was on $31 \%$. Martin, Vikoria, and Gunnar (1999) analyzed the waste wood gasification process from a mill which was coupled with a combined cycle power production system. A photograph of the sample of Babul wood pieces used in the gasifier is shown in Figure 1. The laminar burning velocity of producer gas (at $0.1 \mathrm{MPa}, 300 \mathrm{~K}$ ) is about $0.5 \mathrm{~m} / \mathrm{s}$ as mentioned in the literature (Banapurmath \& Tewari, 2009). It is a low-density energy fuel having low calorific value compared to diesel, natural gas and biogas. The knocking tendency of producer gas is low due to the presence of inert raw gas, carbon dioxide $\left(\mathrm{CO}_{2}\right)$ and nitrogen $\left(\mathrm{N}_{2}\right)$ (Banapurmath \& Tewari, 2009). The main objective of the present work is to test the technical feasibility of using pure Jatropha oil under preheated conditions, and its methyl ester, in combination with woody biomass producer gas in dual fuel mode in a diesel engine as a substitute for diesel fuel.

\section{MATERIALS \& METHODOLOGY}

A schematic diagram of the experimental setup is shown in Figure 2. The experimental setup consists of a single cylinder 4-stroke dual fuel diesel engine coupled with generator and bulb loading devices supplied by Parkas Diesels Pvt. Ltd, Agra. A downdraft type biomass gasifier, gas cooler, and gas filter was supplied by Anker Scientific Energy Technology Pvt. Ltd. Baroda. A photograph of the experimental setup is shown in Figure 3. The detailed specifications of the engine and downdraft woody biomass gasifier are given in Tables 3 and 4 respectively. The biomass is loaded from the top of the gasifier and ash is removed at regular intervals. The partial combustion of biomass in the gasifier reactor is converted into high temperature producer gas, which enters the gas cooler. The moisture, tar and dust particles are removed through two sets of filters. At the outlet of the filter pipe a mechanical valve is provided to control the gas flow rate. For gas flow measurement, an orifice meter and a manometer is connected to a surge tank. Manometers are used to measure air and gas flow separately. The producer gas and air are mixed in the intake pipe and then the mixture enters the engine cylinder. The engine was always operated at its rated speed of $1500 \mathrm{rpm}$, injection timing of $23^{\circ}$ before top dead center (BTDC) and an injection pressure of 220 bars. Tests were carried out under different load conditions using test fuels such as baseline diesel, neat preheated Jatropha oil (PJO) and Jatropha oil methyl ester (Mohammadi, Rafiee, Emam-Djomeh, \& Keyhani) with constant producer gas flow rate in dual fuel mode operation. The Jatropha oil was heated in a shell and tube heat exchanger using engine exhaust gas. In dual fuel operation, the gas flow rate was measured using an orifice meter and manometer attached to the gas surge tank. To obtain a particular gas flow rate, the head difference in the manometer tube was kept constant by rotating a mechanical control valve. For different gas flow rates, the head difference is thus varied by rotating the control valve. The injected diesel flow rate was not maintained as constant. The temperature of the combustion gas before entering the cooling system was measured with the help of a thermocouple and found to be $458{ }^{\circ} \mathrm{C}$, and after cooling and cleaning, was found to be $37^{\circ} \mathrm{C}$.

The performance and emission were observed under different load conditions for all test fuels and compared with the baseline diesel. The AVL make a 5-gas analyzer (model 
No. AVL Degas 444) and smoke meter (model no. AVL $437 \mathrm{C}$ ) with an accuracy of $\pm 1 \%$, which was used to measure exhaust gas emission parameters and smoke opacity respectively. Parameters such as $\mathrm{CO}, \mathrm{HC}$ and $\mathrm{CO}_{2}$ were measured by NDIR (nondispersive infrared) methods and $\mathrm{NO}_{\mathrm{X}}$ and Oxygen $\left(\mathrm{O}_{2}\right)$ were measured using electrochemical methods.

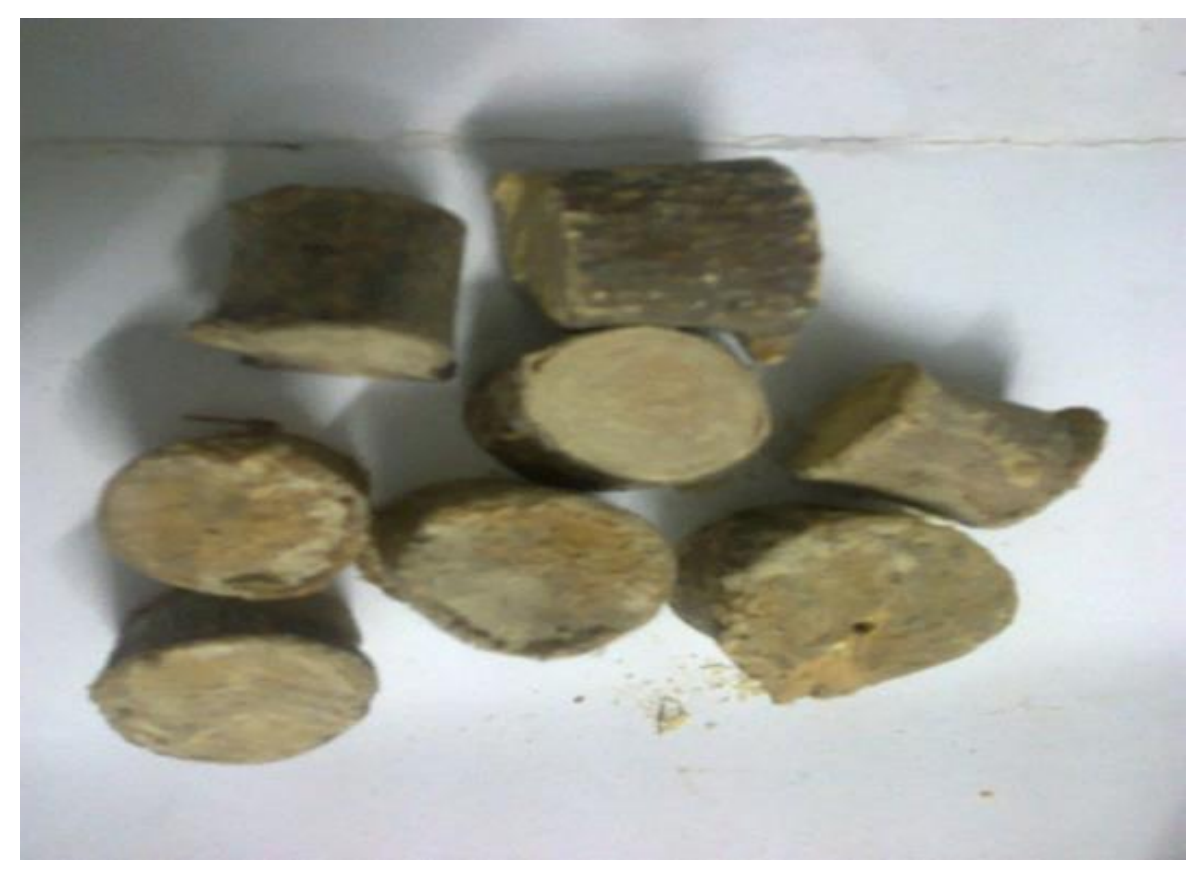

Figure 1. Photograph of sample of wood pieces

Table 1. Composition of producer gas

\begin{tabular}{lccc}
\hline \multicolumn{1}{c}{ Constituents } & Percentage $(\%)$ & \multicolumn{2}{c}{ Levels } \\
\cline { 3 - 4 } & & 16 & High \\
\hline Carbon monoxide & $19 \pm 3$ & 7 & 22 \\
Carbon dioxide & $10 \pm 3$ & 16 & 13 \\
Hydrogen & $18 \pm 2$ & - & 20 \\
Nitrogen & 50 & - & 50 \\
Methane & Up to 3 & & 3 \\
\hline
\end{tabular}

Table 2. Properties of producer gas

\begin{tabular}{lc}
\hline \multicolumn{1}{c}{ Parameters } & Values \\
\hline Calorific value ratio & $1000 \mathrm{Kcal} / \mathrm{NM}^{3}$ \\
Stoichiometric air/fuel & $1.16: 1$ \\
Adiabatic flame & $1546 \pm 25 \mathrm{~K}$ (Banapurmath et al., 2009) \\
temperature & \\
Laminar burning velocity & $0.5 \pm 0.05 \mathrm{~m} / \mathrm{s}$ (Banapurmath et al., 2009) \\
Density & $1.281 \mathrm{Kg} / \mathrm{m}^{3}$ (Banapurmath et al., 2009) \\
Octane number & $100-105$ \\
\hline
\end{tabular}




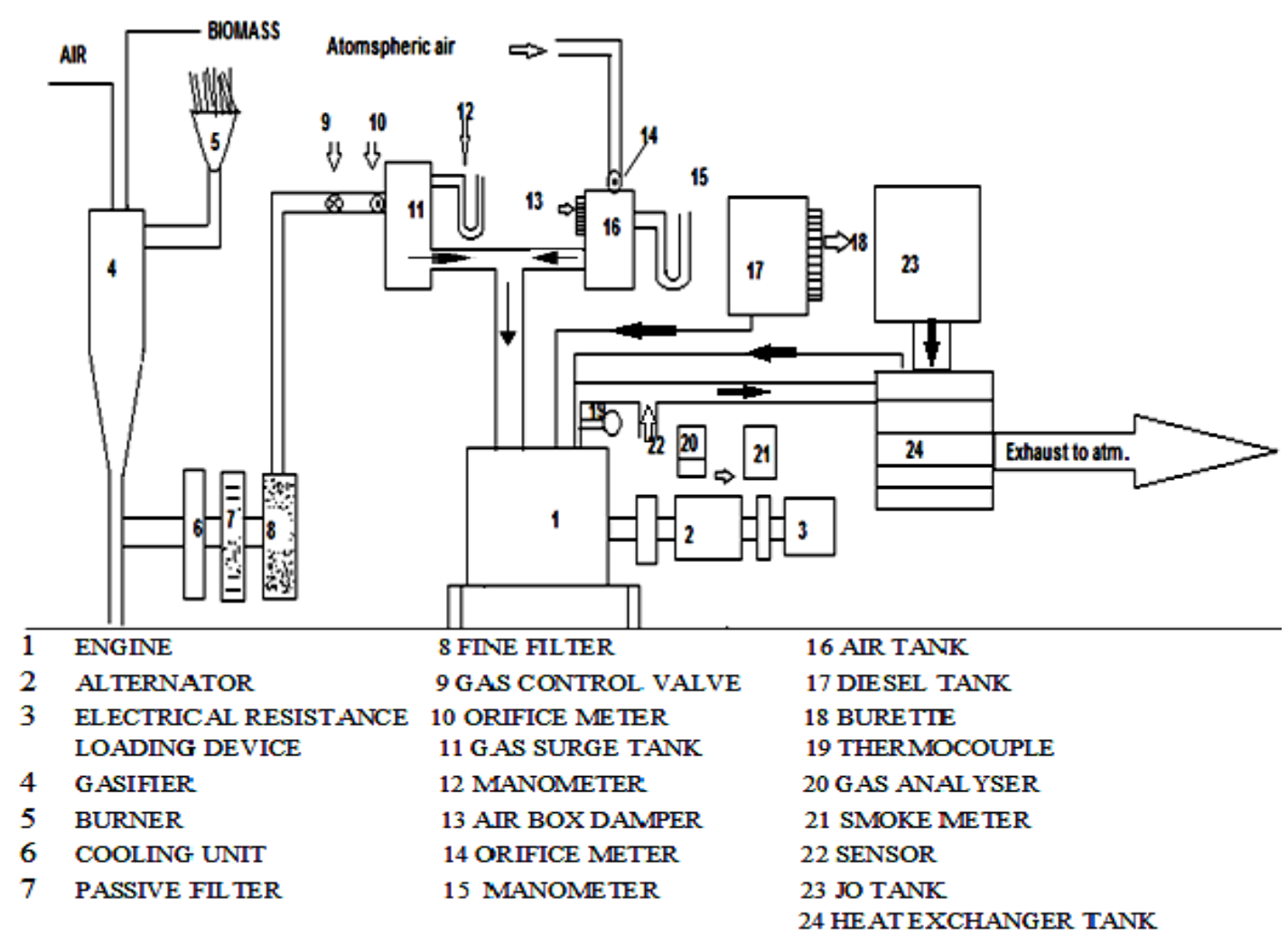

Figure 2. Schematic diagram of the test engine setup

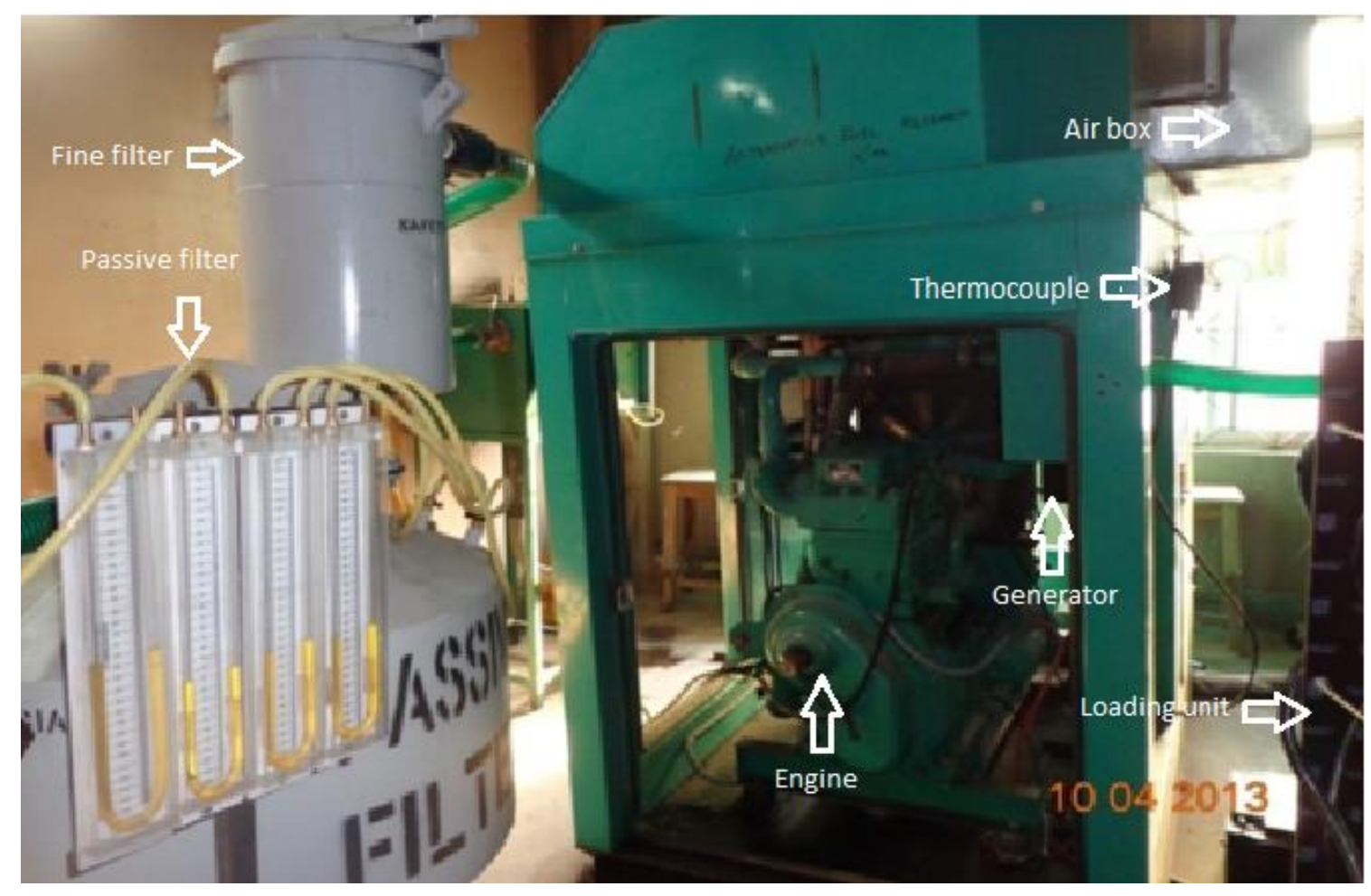

Figure 3. Photograph of the test engine setup with gasifier 
Table 3. Properties of JO, JOME and diesel.

\begin{tabular}{lccc}
\hline \multicolumn{1}{c}{ Property } & Diesel & Jatropha oil & JOME \\
\hline Density $\left(\mathrm{kg} / \mathrm{m}^{3}\right)$ & 830 & 981 & 880 \\
Kinematic viscosity at $40^{\circ} \mathrm{C}(\mathrm{cSt})$ & 2.5 & 37 & 5.65 \\
Calorific value $(\mathrm{KJ} / \mathrm{Kg})$ & 42,500 & 37,500 & 38,450 \\
Cetane No. & 48 & 45 & 50 \\
Cloud point $\left({ }^{\circ} \mathrm{C}\right)$ & -12 & 9 & - \\
Flash point $\left({ }^{\circ} \mathrm{C}\right)$ & 70 & 239 & 171 \\
Pour point $\left({ }^{\circ} \mathrm{C}\right)$ & -17 & 4 & - \\
\hline
\end{tabular}

Table 4. Variation in viscosity of PJO with temperature.

\begin{tabular}{cc}
\hline Temperature $\left({ }^{\circ} \mathrm{C}\right)$ & Kinematic Viscosity of PJO $(\mathrm{cSt})$ \\
\hline 40 & 37.0 \\
60 & 25.1 \\
80 & 17.5 \\
100 & 10.25 \\
120 & 8.2 \\
140 & 6.85 \\
\hline
\end{tabular}

Table 5. Test engine specification

\begin{tabular}{lc}
\hline \multicolumn{1}{c}{ Parameters } & Specification \\
\hline Machine supplier & Ankur Scientific Energy Technologies Pvt. \\
& Ltd. Vadodara - 390 024, India \\
Type & "Prakash" make,7.5 KVA Diesel generating set \\
No. of cylinders & One \\
No. of strokes & $4-$ Stroke \\
Rated power & $7.5 \mathrm{~kW}$ \\
Bore & $80(\mathrm{~mm})$ \\
Stroke length & $110(\mathrm{~mm})$ \\
Compression ratio & $17.5: 1$ \\
Rated speed & $1500(\mathrm{rpm})$ \\
\hline
\end{tabular}

Table 6. Specification of the gasifier used.

\begin{tabular}{lc}
\hline \multicolumn{1}{c}{ Parameter } & Specification \\
\hline Model & WBG -10 in Scrubbed, Clean Gas Mode \\
Rated Gas Flow & $25\left(\mathrm{Nm}^{3} / \mathrm{hr}\right)$ \\
Gasifier type & Downdraft \\
Gasification temperature & $1050-1100\left({ }^{\circ} \mathrm{C}\right)$ \\
Fuel Storage Capacity & $100(\mathrm{Kg})$. \\
Rated hourly consumption & $8-9(\mathrm{Kg})$. \\
Fuel type and size & Wood/woody waste with maximum dimension not exceeding 25 \\
& mm in diameter and length \\
Typical conversion efficiency & $>75 \%$ \\
Permissible moisture content & Less than $20 \%$ (wet basis) \\
in biomass & \\
\hline
\end{tabular}




\section{RESULTS AND DISCUSSION}

\section{Engine Performance Characteristics}

Figure 4 shows the variation in brake thermal efficiency (BTE) with engine load for diesel-Producer gas, PJO-Producer gas and JOME-Producer gas dual fuel operation. Continuous improvement in BTE with increase in load was observed for all dual fuel combinations. This was because with an increase in load, the cylinder charge temperature increases, which promotes better combustion and leads to an increase in BTE. Again, the brake thermal efficiency of PJO-Producer gas operations were found to be lower than JOME-Producer gas and diesel-Producer gas operation. This is attributed to the lower calorific value, higher viscosity and energy consumption of PJO compared to JOME and diesel. A similar result was obtained by Chauhan, Naveen, and Cho (2012). It was also found that at higher engine loads, i.e. above $60 \%$, the increase in BTE for all dual fuel combinations gradually reduces. This is because at $60 \%$ above load, due to fuel richness and incomplete combustion, BTE reduces gradually (Chauhan et al., 2012).

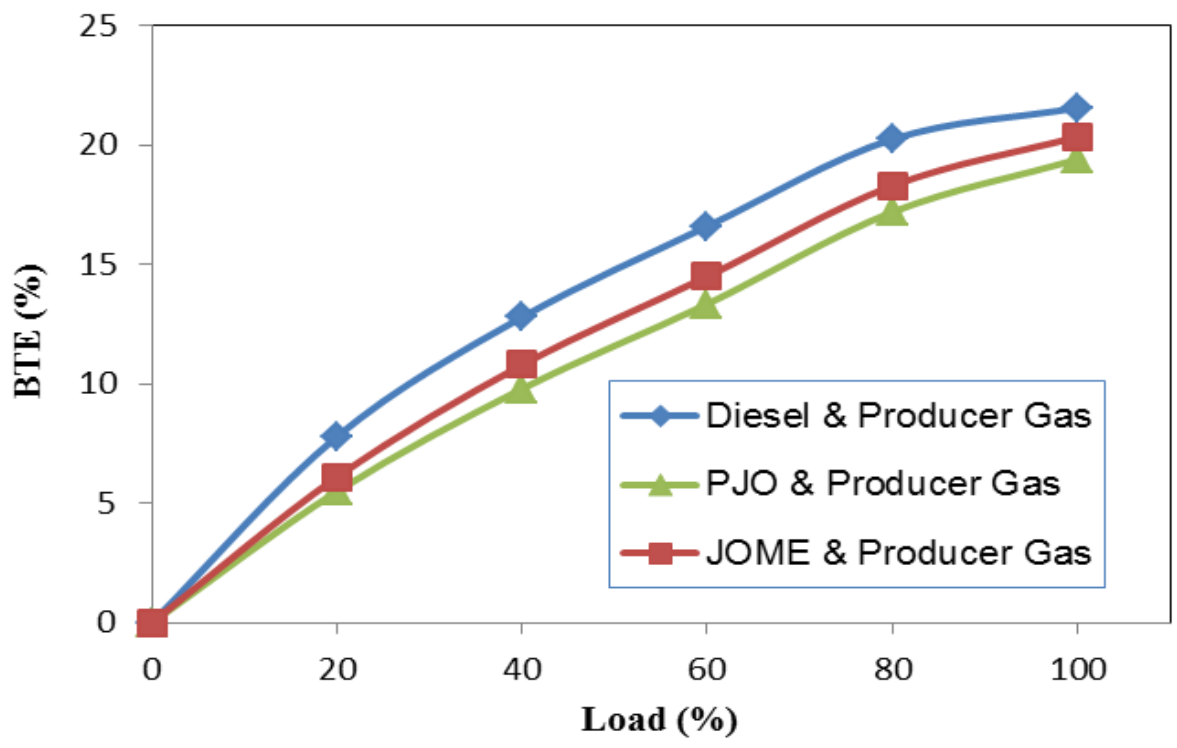

Figure 4.Variation in BTE with Load

The variation in brake specific energy consumption (BSEC) for various engine loads for all test fuels is shown in Figure 5. It can be seen that the BSEC for all test conditions gradually decreases with an increase in load because of improved combustion rates at higher load. The decrease in BSEC is also lower at higher loads for all dual fuel operations. A possible reason is that it is due to better combustion as a result of higher charge temperature at higher load (Chauhan, Naveen, Jun, \& Lee, 2010). It is noted that the highest value of BSEC was obtained with PJO-Producer gas operation compared to JOME-Producer gas and diesel-Producer gas operation. This was due to the higher density, lower heating value and poor atomization of PJO compared to JOME and diesel oil (Chauhan et al., 2012; Chauhan et al., 2010). 


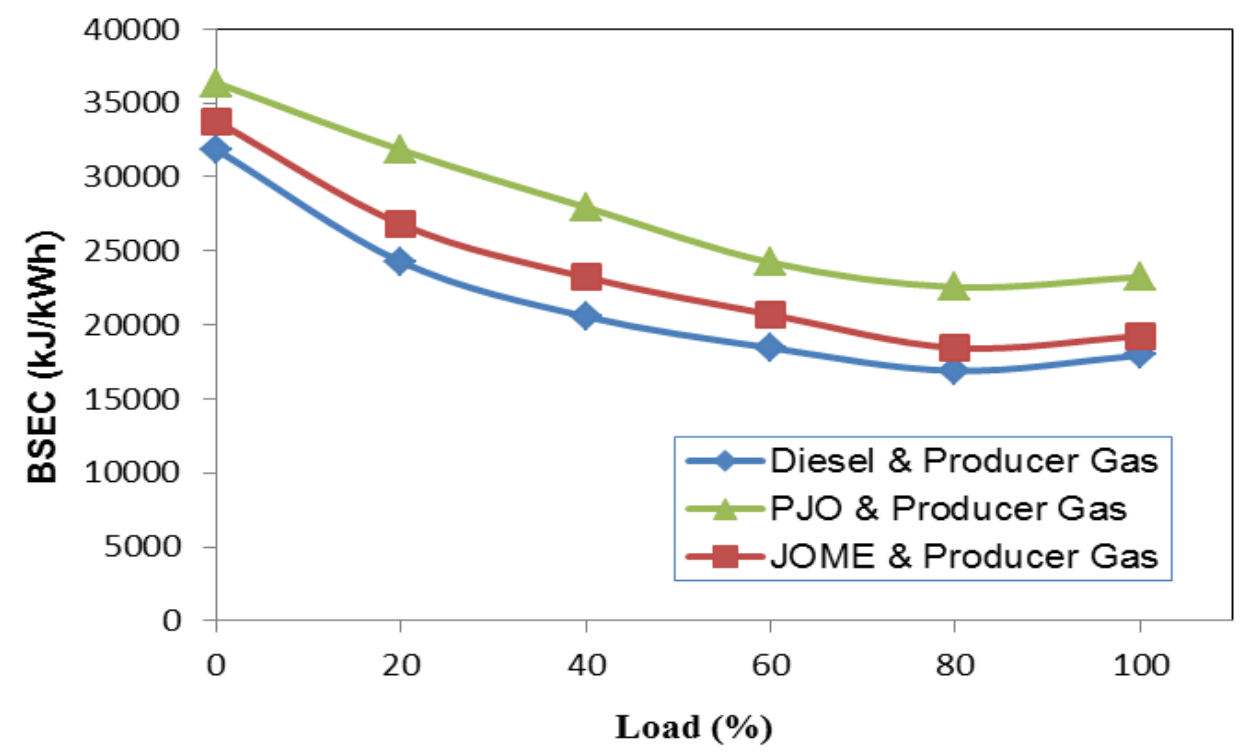

Figure 5. Variation in BSEC with Load

Figure 6 shows the variation in exhaust gas temperature (EGT) with different engine loads for the above three test fuels. It was found that the EGT linearly increases with an increase in engine load for all test conditions. This is due to the fact that at higher engine loads, higher energy is supplied to the engine and the combustion rate is higher, which results in higher EGT (Pattanaik, Nayak, \& Nanda, 2013). The highest value of EGT is obtained with JOME-Producer gas dual fuel operation compared to PJO-Producer and diesel-Producer gas for the range of engine loads. This may be due to the greater availability of oxygen in JOME and PJO molecular structure compared to diesel, which enhances the combustion temperature resulting higher EGT, or may be due to the higher viscosity of JOME and PJO, meaning more energy is released after the combustion phase resulting in higher EGT (Chauhan et al., 2012).

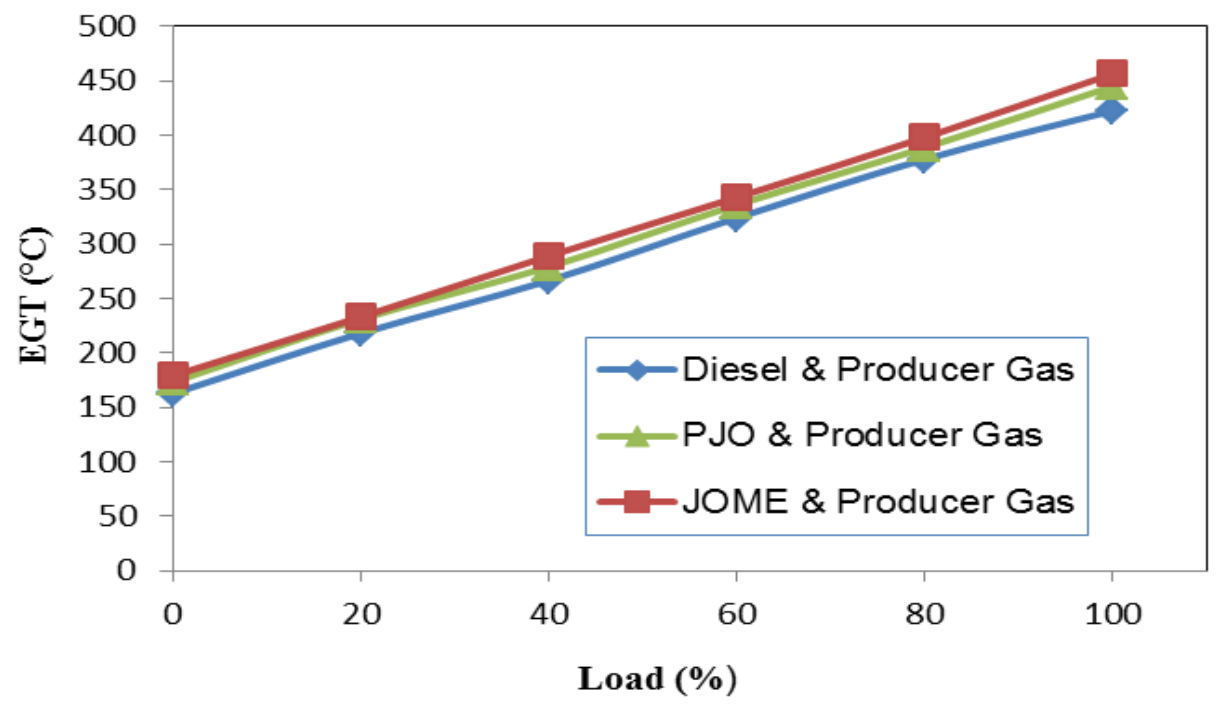

Figure 6. Variation in EGT with load 


\section{Engine Emission Characteristics}

Figure 7 depicts the variation in $\mathrm{HC}$ emissions with engine load for the above mentioned dual fuel engine operations. The results obtained indicate that the HC emission increases with increase in engine load for all three test conditions. This is because at higher engine loads the availability of more fuel in the combustion chamber increases the possibility of incomplete combustion (Chauhan et al., 2012). The HC emissions were found to be highest in the case of PJO-Producer operation due to incomplete combustion as a result of higher viscosity and poor atomization of PJO compared to diesel and JOME. Again the minimum HC emission was found in JOMEProducer gas operation, which is due to the availability of oxygen in the JOME molecular structure which promotes better combustion and thus lowers HC emissions (Chauhan et al., 2012).

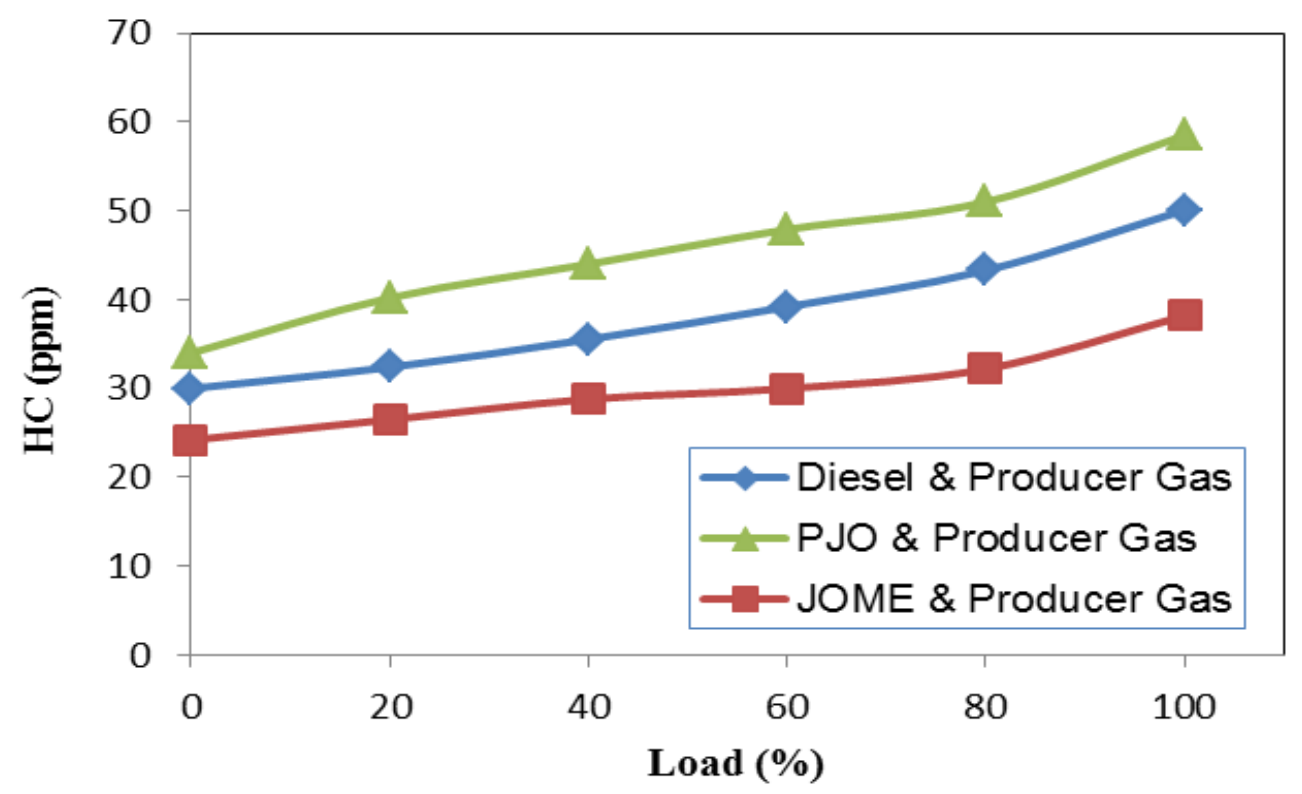

Figure 7. Variation in HC emission with load

Figure 8 shows the variation in $\mathrm{CO}$ emission with engine loads during dual fuel operation with three test fuels. The results obtained show that with an increase in engine load, the $\mathrm{CO}$ emission increases for all test conditions. This is due to the fact that with the increase in load in diesel engines, the fuel flow rate increases by decreasing the fresh air which results in incomplete combustion and thus more $\mathrm{CO}$ emissions (Agarwal \& Rajamanoharan, 2009). The CO emission was found to be highest in PJO-Producer gas due to poor atomization and the higher viscosity of PJO compared to diesel and JOME. However, JOME-Producer gas shows lower values of CO emission compared to dieselProducer gas and PJO-producer gas operation. This is attributed to the higher percentage of oxygen present in JOME molecular structure, which leads to better combustion and generates lower $\mathrm{CO}$ emissions (Chauhan et al., 2012). Figure 9 shows the variation in $\mathrm{CO}_{2}$ emissions with engine loads for all three test conditions in dual fuel mode. It was found that the $\mathrm{CO} 2$ emission increases with an increase in load for all test fuels. With the increase in load, the producer gas flow rate increases, which is a mixture 
of $\mathrm{CO}$ and $\mathrm{CO}_{2}$ resulting in more $\mathrm{CO}_{2}$ emissions during combustion. However, the JOME-Producer gas operation produces the highest $\mathrm{CO}_{2}$ emissions compared to the other two dual fuel combinations. This is due to the availability of more oxygen in the JOME molecular structure, the conversion from $\mathrm{CO}$ to $\mathrm{CO}_{2}$ is enhanced during combustion.

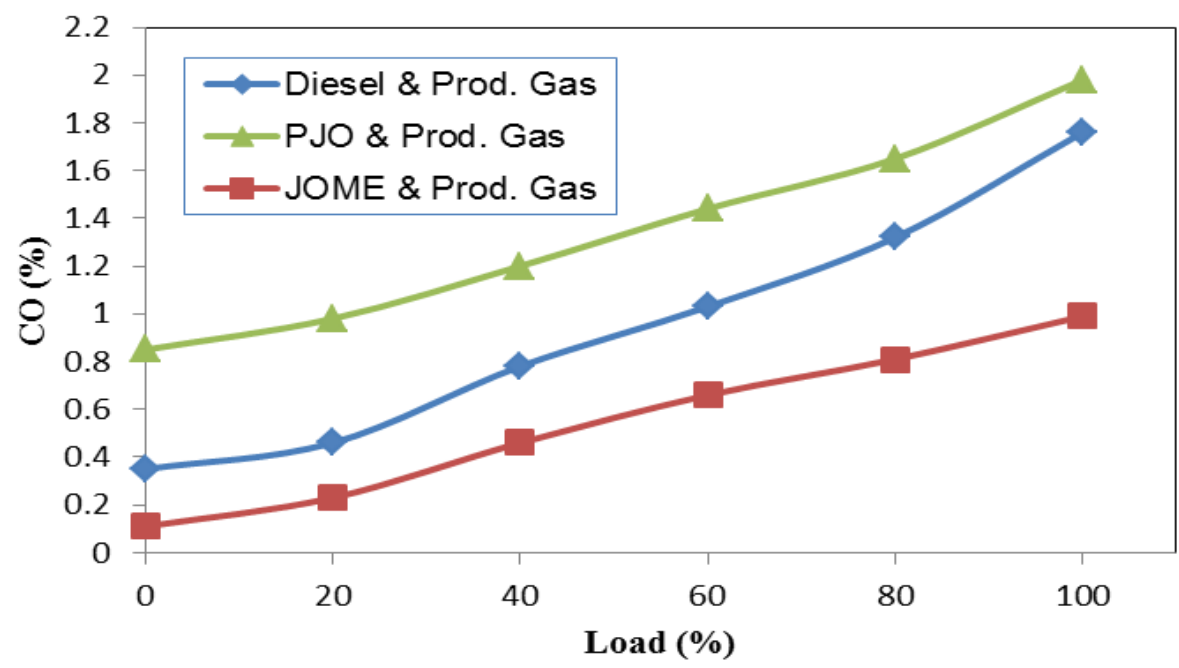

Figure 8. Variation in $\mathrm{CO}$ emission with load

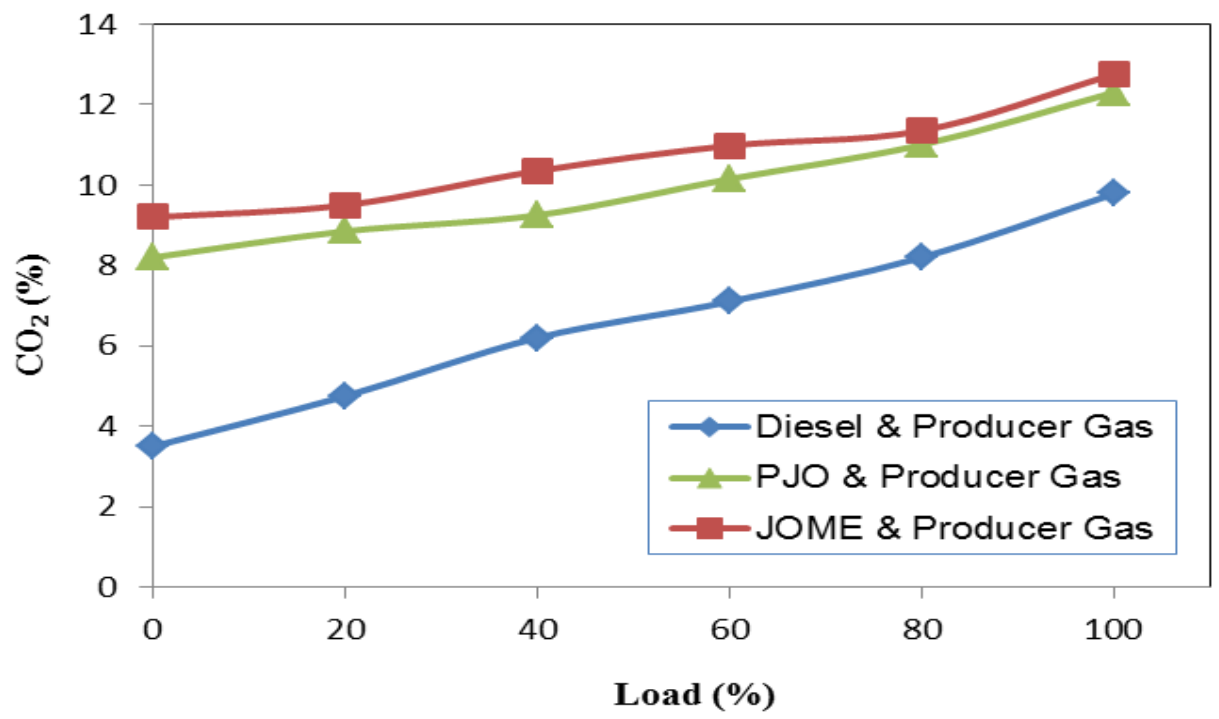

Figure 9. Variation in $\mathrm{CO}_{2}$ emission with load

Figure 10 shows the variation in smoke emissions with engine load. It shows that with an increase in load the smoke emission increase for all test conditions. Again it is found that the combustion in PJO-Producer gas dual fuel mode produces the highest smoke emission due to the higher viscosity of PJO compared to JOME and diesel. Further, it was observed that the smoke opacity level of JOME-Producer gas is higher than that of diesel-Producer gas operation, due to the heavier molecular weight of JOME compared to diesel (Banapurmath, Yaliwal, Hosmath, \& Tewari, 2012; Haiter Lenin, Ravi, Arumugham, \& Thyagarajan, 2012). Figure 11 shows the variation in NOx emission with engine load while operating under all three given test fuels. The results obtained indicate an increase in NOx emissions with an increase in engine load 
for all test fuels. This is because with an increase in load, energy input increases and results in higher combustion temperature, and thus more NOx emissions. It was also found that the NOx emission is highest for vegetable oil (JOME and PJO)-Producer gas operation compared to conventional diesel. This is due to the fact that vegetable oil contains more oxygen. The formation of NOx emissions are basically due to two factors: higher combustion temperature and the availability of oxygen. In a comparison between JOME- Producer gas and PJO-Producer gas operation, JOME- Producer gas shows higher values of NOx emission, because a higher Cetane number and better atomization of JOME compared to PJO leads to higher combustion temperatures resulting in better combustion.

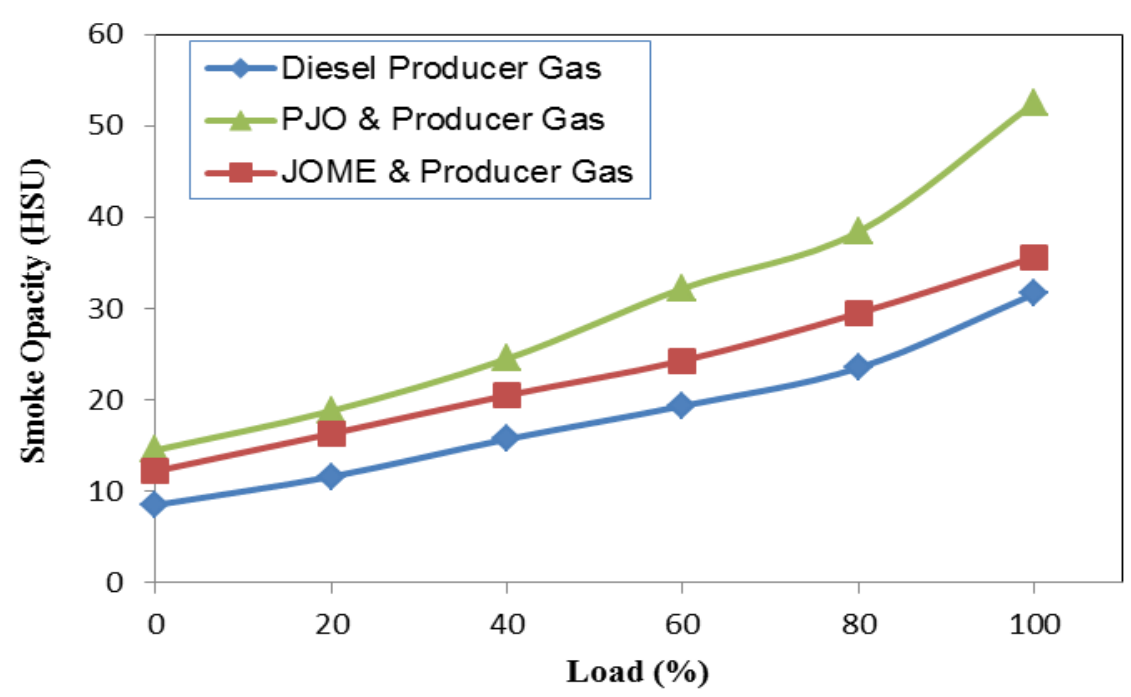

Figure 10. Variation in smoke emissions with load

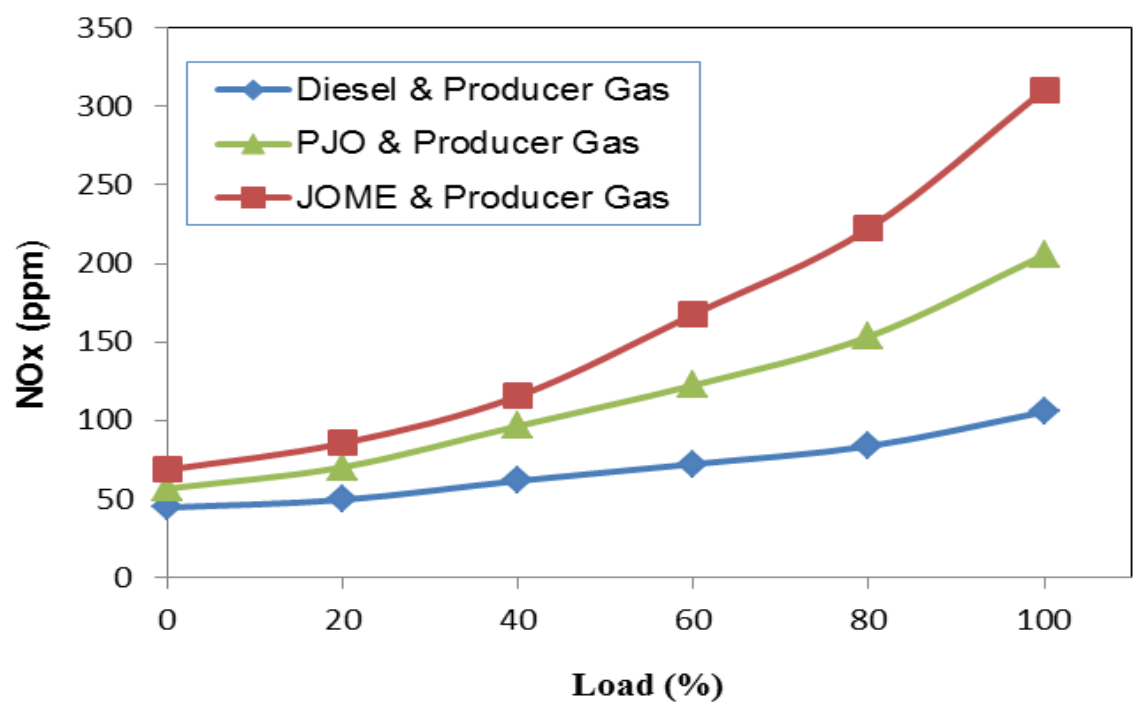

Figure 11. Variation in NOx emission with load

\section{CONCLUSIONS}

The primary objective of the present investigation was to test the effectiveness of PJOproducer gas and JOME-Producer gas in dual fuel mode operation in a single cylinder 
CI engine. The secondary objective was to measure the various engine performances and emission parameters of the above combination of fuels. The following conclusions are drawn from this experimental investigation:

1. The BTE for diesel-producer gas was found to be higher than the other dual fuel operations of the engine, whereas BSEC was found to be lowest for dieselproducer gas and highest for PJO-producer gas dual fuel operation of the engine.

2. The $\mathrm{HC}, \mathrm{CO}$ and smoke emissions were found to be highest for PJO-producer gas dual fuel operation and the lowest for diesel-producer gas dual fuel operation of the engine.

3. The $\mathrm{CO}_{2}$ emission for JOME-producer gas dual fuel operation was found to be highest and lowest for diesel-producer gas operation.

4. The EGT and the NOx emissions were found to be highest for JOME-producer gas dual fuel operation. The same parameters were found to be lowest for dieselproducer gas dual fuel operation of the engine.

\section{REFERENCES}

Agarwal, A. K., \& Rajamanoharan, K. (2009). Experimental investigations of performance and emissions of karanja oil and its blends in a single cylinder agricultural diesel engine. Applied Energy, 86, 106-112.

Azad, A. K., Ameer Uddin, S. M., \& Alam, M. M. (2012). A comprehensive study of di diesel engine performance with vegetable oil: An alternative boi-fuel source of energy. International Journal of Automotive and Mechanical Engineering, 5, 576-586.

Aziz Hairuddin, A., Wandel, A. P., \& Yusaf, T. (2013). Effect of different heat transfer models on a diesel homogeneous charge compression ignition engine. International Journal of Automotive and Mechanical Engineering, 8, 12921304.

Banapurmath, N. R., \& Tewari, P. G. (2009). Comparative performance studies of a 4stroke ci engine operated on dual fuel mode with producer gas and honge oil and its methyl ester (home) with and without carburetor. Renewable Energy, 34, 1009-1015.

Banapurmath, N. R., Yaliwal, V. S., Hosmath, R. S., \& Tewari, P. G. (2012). Life improvement programme of producer gas-biodiesel operated dual fuel engines. International Journal of Sustainable Engineering, 5(4), 350-356.

Bari, S., Lim, T. H., \& Yu, C. W. (2002). Effect of preheating of crude palm oil on injection system, performance and emission of a diesel engine. Renewable Energy, 27, 339-351.

Chairman, C. o. D. o. B.-f. (2003). Report of committee on development of bio-fuels. In Commission, P. (Ed.), Government of India. India.

Chauhan, B. S., Naveen, K., \& Cho, H. M. (2012). A study on the performance and emission of a diesel engine fueled with jatropha biodiesel oil and its blends. Energy, 37, 616-622.

Chauhan, B. S., Naveen, K., Jun, Y. D., \& Lee, K. B. (2010). Performance and emission study of preheated jatropha oil on medium capacity diesel engine. Energy, 35, 2484-2492. 
Edwin, G. V., Nagarajan, G., \& Nagalingam, B. (2008). Studies on dual fuel operation of rubber seed oil and its bio-diesel with hydrogen as the inducted fuel. International Journal of Hydrogen Energy, 33, 6357-6367.

Ghobadian, B., Najafi, G., \& Nayebi, M. (2013). A semi-empirical model to predict diesel engine combustion parameters. Journal of Mechanical Engineering and Sciences, 4, 373-382.

Haiter Lenin, A., Ravi, R., Arumugham, S., \& Thyagarajan, K. (2012). Performance, emission and combustion evaluation of diesel engine using methyl esters of mahua oil. International Journal of Environmental Sciences, 3, 639-649.

Kalam, M. A., \& Masjuki, H. H. (2004). Emissions and deposit characteristics of a small diesel engine when operated on preheated crude palm oil. Biomass Bioenergy, 27, 289-297.

Krishna, K. S., \& Ajit Kumar, K. (1994). A study for the utilization of coffee husk in diesel engine by gasification. Paper presented at the Biomass gasification technology, India

Lata, D. B., \& Misra, A. (2010). Theoretical and experimental investigations on the performance of dual fuel diesel engine with hydrogen and lpg as secondary fuels. International Journal of Hydrogen Energy, 35, 11918-11931.

Martin, A., Vikoria, M., \& Gunnar, S. (1999). Combined production of power and alternative fuels in connection with pulp mills. SAE Technical Paper No. 199901-2470.

Mat Yasin, M. H., Mamat, R., Sharma, K. V., \& Yusop, A. F. (2012). Influence of palm methyl ester (pme) as an alternative fuel in multicylinder diesel engine. Journal of Mechanical Engineering and Sciences, 3, 331-339.

Mohammadi, A., Rafiee, S., Emam-Djomeh, Z., \& Keyhani, A. (2008). Kinetic models for colour changes in kiwifruit slices during hot air drying. World Journal of Agricultural Sciences, 4(4).

Murugesan, A., Umarani, C., Subramanian, R., \& Nedunchezhian, N. (2009). Bio-diesel as an alternative fuel for diesel engine - a review. Renewable and Sustainable Energy Reviews, 13, 653-662.

Nwafor, O. M. I. (2000). Effect of choice of pilot fuel on the performance of natural gas in diesel engines. International Journal Renewable Energy, 21, 495-504.

Pattanaik, B. P., Nayak, C. K., \& Nanda, B. K. (2013). Investigation on utilization of biogas and karanja oil biodiesel in dual fuel mode in a single cylinder di diesel engine. International journal of Energy and Environment, 4, 279-290.

Pradeep, V., \& Sharma, R. P. (2007). Use of hot egr for nox control in a compression ignition engine fuelled with biodiesel from jatropha oil. Renewable Energy, 32, 1136-1154.

Rahim, R., Mamat, R., Taib, M. Y., \& Abdullah, A. A. (2012). Influence of fuel temperature on a diesel engine performance operating with biodiesel blended. Journal of Mechanical Engineering and Sciences, 2, 226-236.

Ramadhas, A. S., Jayaraj, S., \& Muraleedharan, C. (2008). Dual fuel mode operation in diesel engines using renewable fuels: Rubber seed oil and coir-pith producer gas. Renewable Energy, 33, 2077-2083.

Senthil Kumar, M., Ramesh, A., \& Nagalingam, B. (2001). Investigations on the use of jatropha oil and its methyl ester as fuel in a ci engine. Journal Inst Energy, 74, 24-28. 
Senthil Kumar, M., Ramesh, A., \& Nagalingam, B. (2003a). An experimental comparison of methods to use methanol and jatropha oil in a compression ignition engine. Biomass Bioenergy, 25, 309-318.

Senthil Kumar, M., Ramesh, A., \& Nagalingam, B. (2003b). Use of hydrogen to enhance the performance of a vegetable oil fuelled compression ignition engine. International Journal of Hydrogen Energy, 28, 1143-1154.

Sharma, R. P. (2003). Bio-diesel and e-diesel in transportation-an oem perspective. Paper presented at the XVIII National Conference on IC Engines.

Soon, L. B., Rus, M., Anika, Z., \& Hasan, S. (2013). Continuous biodiesel production using ultrasound clamp on tubular reactor. International Journal of Automotive and Mechanical Engineering, 8, 1396-1405.

Sundar Raj, C., \& Sendilvelan, S. (2010). Effect of oxygenated hydrocarbon additives on exhaust emission of a diesel engine. International Journal of Automotive and Mechanical Engineering, 2, 144-156.

Szybist, J. (2003). Potential methods for nox reduction from bio-diesel. SAE Transaction, 27-33.

Yusaf, T., Hamawand, I., Baker, P., \& Najafi, G. (2013). The effect of methanol-diesel blended ratio on ci engine performance. International Journal of Automotive and Mechanical Engineering, 8, 1385-1395.

NOMENCLATURE

\begin{tabular}{ll}
\hline Parameters & Description \\
\hline $\mathrm{CI}$ & Compression Ignition \\
$\mathrm{DI}$ & Direct Injection \\
JOME & Jatropha oil Methyl Ester \\
$\mathrm{JO}$ & Jatropha Oil \\
$\mathrm{PJO}$ & Preheated Jatropha Oil \\
$\mathrm{CNG}$ & Compressed Natural Gas \\
$\mathrm{LPG}$ & Liquefied Petroleum Gas \\
$\mathrm{JOBD}$ & Jatropha oil Bio-diesel \\
$\mathrm{ACA}$ & Alternating Current \\
$\mathrm{N}_{2}$ & Nitrogen gas \\
$\mathrm{HC}$ & Hydrocarbon \\
$\mathrm{CO}$ & Carbon monoxide \\
$\mathrm{CO}$ & Carbon dioxide \\
$\mathrm{NO}$ & Nitrogen oxide \\
$\mathrm{HSU}$ & Heritage Smoke Unit \\
$\mathrm{MJ} / \mathrm{m}^{3}$ & Mega Joules per Cubic meter \\
$\mathrm{Kg} / \mathrm{m}^{3}$ & Kilo grams per cubic meter \\
$\mathrm{KJ} / \mathrm{kg}$ & Kilo Joules per Kilogram \\
$\mathrm{cSt}$ & Centi Stokes \\
$\mathrm{w} / \mathrm{w}$ & Weight by weight \\
$\mathrm{rpm}$ & Revolutions per minute \\
$\mathrm{Nm} / \mathrm{hr}$ & Newton cubic meter per hour \\
$\mathrm{KJ} / \mathrm{KWhr}$ & Kilo Joules per Kilo Watt hour \\
$\mathrm{Ppm}$ & Parts per million \\
$\mathrm{NM}$ & Normal cubic meters \\
\hline
\end{tabular}

